\title{
Study on the Infiltration of Excellent Traditional Culture in College Students' Ideological and Political Education
}

\author{
Qiaoli Zhang
}

Weinan Normal University, Weinan, Shaanxi, 714000

\begin{abstract}
Keywords: College students, ideological and political education, excellent traditional culture
\end{abstract}
\begin{abstract}
The traditional culture of the Chinese nation is gradually formed and developed by the Chinese nation in the course of long-term historical development. Its long-term spread will have an important impact on the entire society, permeating the entire character of the Chinese nation, and the ethics of various manifestations Therefore, the traditional culture plays an irreplaceable role in the ideological and political education. To a certain extent, the study of the ideological and political traditions is precisely the fine traditional culture of China, the traditional virtues, and the fine revolutionary tradition Inheritance and development, the Chinese excellent traditional culture into the ideological and political education can not only enrich the content of ideological and political education, but also can improve teaching effectiveness. The article mainly focuses on the infiltration of excellent traditional culture in the work of ideological and political education.
\end{abstract}

\section{Introduction}

The excellent traditional culture of the Chinese nation is formed after 5,000 years of historical development. After thousands of years of sedimentation and development, it still has strong vitality and profound implications even today in the information explosion. Chinese outstanding traditional culture advocates take the lead in setting examples, establish oneself and others, moral education also follow the principle of individualized teaching, step by step, in order to achieve the unity of moral understanding and moral practice, which all provide useful reference for the modern ideological and political education. In ideological and political education in colleges and universities, based on the long history and profound Chinese tradition of excellence, the Chinese nation's moral and cultural pursuits are incorporated into the students 'life and life. The excellent traditional culture cultivates students' sentiments and enhances their moral qualities, Improve their personality.

The traditional culture of the Chinese nation always pays great attention to the cultivation of individual moral accomplishments. Personality cultivation emphasizes the tenets of "gentleness, courtesy, and benevolence, righteousness and righteousness, wisdom and trust", and "harmony is precious" when people get along with others. Do not impose on others "," Do not regard evil as small, not as good as small but not "to be strict with oneself. The spirit of collective cooperation is reflected in" Lutheran sincerely "and so on, these values, outlook on life will have a direct or indirect impact on the formation of college students' moral character. Therefore, incorporating Chinese excellent traditional theory into ideological and political education can help them to establish a correct outlook on life, values and moral values, and cultivate their attitude of being proactive, tolerant and open-minded.

For thousands of years there have been countless ethnic English and benevolent lore in the history of our country, leaving many popular stories in the historical data. It can be said that the history and cultural traditions of the Chinese nation are inherited from patriotism. Patriotism has created tremendous solidarity and cohesion in the development of the Chinese nation. From elementary school textbooks to college courses, we have learned a lot of patriotic verses, such as "Ahead of the worries and worries, after the world of music and music", such as "Who ever died in life, leaving Dan Xinshun history", and then to "the rise and fall of the world, every man has the responsibility" and so on, these poetry and song are shining the glory of patriotism. However, incorporating such lofty patriotism into ideological and political education can enhance students' 
sense of national pride and social responsibility, strengthen their national consciousness and cultivate their patriotic sentiments.

\section{The lack of excellent Chinese traditional culture in college ideological and political education}

Although traditional culture plays an irreplaceable role in ideological and political education in colleges and universities, the integration of excellent traditional culture and ideological and political education is far from enough in actual teaching. The main defects are as follows:

With the continuous expansion of enrollment in universities, the cultivation of higher qualified personnel is also more focused on the training of skilled personnel. Professional courses occupy more and more of the proportion of higher education institutions, and the ideological and political education lacks attention. Although the CPC Central Committee's "Opinions on Further Strengthening and Improving College Students' Ideological and Political Education" clearly states that it is necessary to carry out an in-depth education of the national spirit for contemporary college students and give full play to the role of traditional culture. However, most of the colleges and universities only conducted publicity for certain aspects, and did not make practical and systematic courses, resulting in the infiltration of excellent traditional culture into a formality. At present, the major ideological and political education courses in colleges and universities take the theoretical knowledge of Mao Zedong Thought and the basic principles of Marxism as the core. There are few contents related to China's outstanding cultural traditions. Even if some courses are offered in traditional culture in schools, their courses as elective courses Not only the content is small, but the structure is also not reasonable, resulting in students can only touch the fur of traditional culture, can not thoroughly understand its essence.

At this stage, we should pay attention to the fact that the integration of traditional culture and ideological and political education is too "mechanized". That is to say, the teacher did not carry out an in-depth and thorough explanation of the essence, concept and position of the traditional culture during the education of traditional culture The education of traditional culture is too simple, only transplanting some sentences in traditional culture, resulting in the education of traditional culture in the ideological and political education turned into superficial teaching such as reciting the classic and adopting the traditional ritual, The conversion and re-creation not only fail to exert its good educational function, but also may lead to the drossing factors in the traditional culture. On the contrary, they have a negative impact on college students' values and outlook on life. In addition, the traditional culture is out of touch with the life of college students. It can be said that the outstanding traditional culture is only the "embellishment" of the daily life of college students. It is not really integrated into the study and life of college students. For example, the education of traditional culture is only taught in the classroom and does not extend to the students' Life, resulting in classroom education and education are separated from each other.

With the large-scale enrollment of colleges and universities, the number of college students has risen sharply, but the pressure of undergraduates learning more and more, followed by increasing employment pressure, students in order to improve their employment competitiveness, often the majority Time and energy on examinations of various kinds of certificates, unable to take into account the traditional Chinese culture and learning, the utilitarian nature of education is becoming more and more prominent. It is generally accepted that natural sciences have a direct role in promoting the development of productive forces and therefore curricula tend to be natural sciences. But for one nation and one country, the future of the national nation is worrisome if only the economy is developed and the education is backward. Simply study the professional knowledge and ignore the study of humanities science system can not gain theoretical thinking, so we must strengthen the traditional culture of learning and construction.

\section{The ideological and political education into the excellent traditional culture strategy}

In view of the lack of traditional culture in ideological and political education in colleges and 
universities, it is suggested to strengthen the education and study of excellent traditional culture from the following aspects:

General Secretary Xi Jinping emphasized the importance of cultivating and promoting the core values of socialism with the fine traditional Chinese culture and has an important spiritual significance for the inheritance of the cultural heritage of a country and nation. China's outstanding traditional culture carries the heavy responsibility of inheriting the spirit of the Chinese nation. As the new force of society, college students inherit the essence of excellent traditional culture. Therefore, the ideological and political education in colleges and universities should take "taking Lide Tree as the fundamental task of education This concept as a guide, in ideological and political education to give full play to the important role of outstanding traditional culture, guide students to identify with mainstream culture, local culture, to develop their patriotic feelings, to help students establish a correct outlook on life and values, and improve their ideological and political Cultivation of quality and morality through the education of Chinese excellent traditional culture to enhance students' national pride and self-confidence.

Campus culture is an important carrier of traditional culture and education. Therefore, university administrators should give full attention to the creation of excellent traditional culture and provide a good learning environment for students. For example, establishing a traditional cultural famous aphorisms or poetic inscriptions on campus, establishing saints and statues, hanging pictures of cultural scholars and so on, deepen students' understanding of traditional culture. We will use traditional school newspapers, websites, radio stations and other forms of media to promote traditional culture. We will open up columns of traditional culture in schools and attract students to participate in various forms through diversified contents. In addition, it is also possible to establish traditional cultural student clubs in schools or to hold campus culture and arts festivals on the basis of traditional culture, to organize students to watch traditional and cultural film and television works and to invite traditional opera to campus. This not only enriches the daily life of college students, can narrow the distance between traditional culture and students 'learning life, subtly improve students' humanities accomplishment, create a more healthy personality.

The teacher should reasonably apply the more energetic discourse, content and spirit in traditional culture to the ideological and political education, give full play to the advantages of traditional culture, explore the meeting point of excellent traditional culture and college students' ideological and political education through cultural consciousness, the combination of the two produces a synergistic effect. The actual teaching process should be rich in teaching methods to enable students to more in-depth, more comprehensive understanding of traditional culture, such as theory, alchemy, explain examples and so on, to develop a wealth of teaching resources to improve college students' political literacy, personality cultivation and Patriotic feelings. In addition, we must also inherit and develop the spirit of traditional culture, enable students to have a sense of awe in traditional culture, enhance student-teacher interaction through "restitution of traditions" and "modern comparison", tap the essence of traditional culture, avoid deconstruction of traditional culture in the form of "overconsumption" and "spoof" so as to prevent students from misinterpreting the unique charm of traditional culture.

\section{Conclusion}

In short, Chinese traditional culture is a cultural form that has developed, precipitated and precipitated by the Chinese nation for thousands of years and has become more stable. It is also the crystallization of wisdom of the Chinese nation. Traditional culture has long-lasting and penetrating influence. Integrating traditional culture and education into ideological and political education in colleges and universities can improve students' moral standards and enhance their patriotic feelings, so as to enhance students' pride and self-confidence, improve students' outlook on world and outlook on life, Values. Therefore, as an important position of ideological and political education, college students' ideological and political education have the obligation to carry forward and inherit the essence of traditional culture, to integrate the valuable and meaningful theoretical achievements and ideological understanding in traditional culture into innovative ideological and political 
education Of ideological and political education; of course, the actual education should pay attention to absorb the best, abandon dross, and improve the effectiveness of ideological and political education of college students.

\section{References}

[1] LI Li-ping, WANG Zhi-xiong an Analysis of the Innovation Mode of Socialization of Higher Education: From the Perspective of Combination of Ideological and Political Education with Community Service [J]. Journal of Chongqing Three Gorges University, 20156 (4): 142-146.

[2] Zheng Jianzhong, Zhang Xiaohong. Nothingness • Universal • Barriers: Three Major Challenges and Criticisms of Ideological and Political Education in Colleges and Universities [J]. Journal of Chongqing University of Technology: Social Sciences Edition, 2015 (9): 115-120

[3] Wu Shuxian, A Jianbo. Journal of China Three Gorges University (Humanities and Social Sciences), 2017 (6): 26-29. Education Innovation of Ideological and Political Theory Course in Colleges and Universities under the New Media Field of Vision - A Case Study of Some Universities in Hubei Province [J].

[4] Zhang Miao. Journal of Yangtze River Normal University, 2015 (4): 126-130 Comment on the Application of "Micro-class" in Ideological and Political Theory Course in Colleges and Universities - Taking the Course of "Ideological and Moral Cultivation and Law Basis" as an Example [J].

[5] Li Hong. Journal of Chongqing Three Gorges University "2017-03 Add to Favorite Get Latest Update Rational Thinking on Strengthening the Teaching of Ideological and Political Theory in Independent Colleges [J]. Journal of Chongqing Three Gorges University, 2017 (1): 145-148.

[6] Wang Liping. Journal of Chongqing University of Technology: Social Sciences Edition, 2015 (6): 80-84. [J]. Journal of Chongqing Institute of Technology: Social Sciences Edition, 2015 (6): 80-84. 